\title{
AN ANALYSIS OF THE USE OF BRITISH ENGLISH AND AMERICAN ENGLISH TOWARD WRITING ABILITY IN THE STUDENTS' INSTAGRAM ACCOUNTS OF NAHDLATUL ULAMA UNIVERSITY OF PURWOKERTO
}

\author{
Ade Christanty Yudha Bestari ${ }^{1}$, Meilina Haris Mayekti ${ }^{2}$, Dinar Faiza ${ }^{3}$ \\ ${ }^{1}$ English Language Teaching Department, Faculty of Social, Economics and Humanities, \\ Nahdlatul Ulama University of Purwokerto, Purwokerto, Indonesia) \\ acy.bestari@gmail.com \\ ${ }^{2}$ English Language Teaching Department, Faculty of Social, Economics and Humanities, \\ Nahdlatul Ulama University of Purwokerto, Purwokerto, Indonesia) \\ meilina.haris@gmail.com \\ ${ }^{3}$ English Language Teaching Department, Faculty of Social Economics and Humanities, \\ Nahdlatul Ulama University of Purwokerto, Purwokerto, Indonesia) \\ dinarfaiza1689@gmail.com
}

\begin{abstract}
This research contains an analysis of the use of British and American English on writing skills on student accounts of the Nahdlatul Ulama Purwokerto University (UNU Purwokerto). The purpose of this study was to analyze the British English and American English vocabularies toward writing ability in the students' Instagram accounts of Nahdlatul Ulama University of Purwokerto. This study uses a qualitative approach using descriptive analysis methods. The sampling technique was carried out by means of purposive sampling of the captions used for English writing practice. The Instagram account analyzed was the Instagram account of the Purwokerto Nahdlatul Ulama University students. The accounts analyzed were 50 students accounts. The results of this study showed, the researchers analyzed the differences between British English and American English in the captions on students' Instagram. Second, the researchers analyzed writing skills regarding the suitability of grammatical with sentences context. Third, the researchers could arrange glossary of British and American English Vocabularies to support in developing English writing skills.
\end{abstract}

Keywords: British dan American English; writing; instagram caption

In the era of globalization, mastering English is something that must be owned by every individual. This is the main tool used to build communication and compete globally. English is the language used as a medium of communication and as the first international language used to interact with other people around the world. English is a Germanic language that was first spoken in
England in the early medieval period. And now it has become the official language and most commonly used in nearly 60 countries around the world. There are four aspects of language skills taught in English, namely reading, writing, listening and speaking. In this case the four skills have a high contribution and can be used as an indication of increasing the ability of students 
effectively, because these four skills are part of language which is essentially a means of communication. Even though writing is one of the most important abilities. Writing skills must be trained and practiced regularly. So that the use of the popular media Instagram in the era of technological advancement is one way of developing writing skills.

The Proposes 21st century skill consist of an integrated of content knowledge, particular skills, proficiency, and literacy of technologies which inslude skill in critical thinking, problem solving, communication, and team work (Ledward and Hirata in Fandino, 2013).

From the quote above, we have to build the skills such as integrated content knowledge, specific skills, skills, and technological literacy which include skills in critical thinking, problem solving, communication, and teamwork. The ability to write is one of the indicators seen to assess the progress of a nation. The level of national progress can be assessed from the habits of the community in practicing writing habits. There are many technological tools in the form of web 2.0 technologies, for instance wiki, blog, podcast, instant messenger, online social communities, online video sharing, an online video and audio conferencing tools in which they give contribution to teaching and learning in 21 st digital age. On of types Web 2.0 that the students are familiar with is an instagram as online social communities (Koc and Koc, 2016). Social media is the online communities in which people interact to each other. Social networking activities have the possibility of enhancing lecturers' professional and adding media/ways in their teaching. Social Media users can create and organize a profile for them, edit and comment on each other's posts and share information to each other. The instagram as one of the famous social media, it can be well integrated into their world and society in general. Inference, social media is digital and online communities to build interaction with others. The students are familiar with Instagram as an online social community. Instagram is one of the social network platforms in which the students usually use it to share their personal information, such as uploading their pictures or videos and writing Instagram captions (Agustrianita, 2017) .

In addition, Instagram is a photosharing mobile application that allows users to take pictures, apply filters to them, and share the on the platform itself. Instagram has over 400 million active monthly users who shared over 40 billion pictures Alhabash and Ma (2017). The students have different perspectives about the use of instagram in teaching and learning process. The notion of perspective derives from the idea of viewpoints or perception about a case of applying instagram (Anggraeni, 2017). Perception is an external factor on participants' point of view, understanding, belief, and reaction to an innovation (Johnson in Alnujaidi, 2017).

Regarding to the phenomenon of using social media, it is needed to use social media platform in teaching and learning process of English class especially in improving writing skill. In the recent years, there has been a growing concern developing in writing skills in the higher education. Learners go on into specific knowledge acquiring situation which is their writing has to be more specific oriented (Rahman, 2009). Writing is the most focused but the least developed English language skill among the university learners a (Rahman, 2009).

According to previous research, social media is an online community where people interact with each other. Social networking activities have the possibility to enhance lecturers' professionalism and add media / means in their teaching. The 
lecturers will be close to their students and will be interactive to enrich the competence of English students. Students and lecturers can arrange activities such as writing skills, grammar comprehension, and so on. Social Media users can create and manage profiles for them, edit and comment on each other's posts and share information with each other. Instagram as one of the well-known social media, can be well integrated into the world and their society in general. In conclusion, social media is a digital and online community to build interactions with other people. Students are familiar with Instagram as an online social community. Instagram is one of the social networking platforms where students usually use it to share their personal information, such as uploading their pictures or videos and writing Instagram captions.

Writing skills are an important part of communication for students throughout their academic life because it allows them to organize their feelings and ideas clearly as well as to convey meaning through well-constructed text (Widagdo, 2017). Writing is both a physical and mental act. At the most basic level, writing is the physical act of committing words or ideas to some medium. On the other hand, writing is the mental work of inventing ideas, thinking about how to express them, and organizing them into statements and paragraphs that will be clear to a reader (Nunan, 2003).

Developed countries tend to have a high level of intellectuality because of the habits and writing skills of their high society. Writing is one basic skill in learning English beside listening, speaking, and reading. Writing means producing or creating a piece of text. That is why it belongs to productive skills together with speaking (Harmer, 2001). Many previous studies have also examined the use of other social media such as Facebook. The use of Facebook as teaching and learning media bring many benefits for students (Khusnita, 2017).

In addition, in the world of education and the world of work. The ability to write is an added value for us. Because of this, teachers use many methods in the writing learning process. Among the media used is the popular social media Instagram. Instagram is a photo-sharing mobile application that allows users to take pictures, apply filters to them, and share them on the platform itself. Instagram has over 400 million active monthly users who shared over 40 billion pictures (Alhabash and Ma, 2017). Uploading writing assignments in instagram is one of types of online assigments. Throghout the writing assigments that shoud be submitted in instagram, there are benefits and barriers of using instagram in writing class that are shown based on the students perspectives (Anggraeni, 2017). Sharing pictures online in social networking platform such as instagram is an omnipresent practice (Zappavigna, 2016).

Students need to understand the differences between British English and American English in order to be precise and have a good written language. Lexicon or vocabulary is a central linguistic area where there are noticeable differences between British English and American English (Fares, 2019).

Spoken English has wide variation in pronunciation. According to there are 3 Standard English pronunciations are distinguished and spoken. 1) The Received Pronunciation, called Oxford English, is the standard of British English; 2) The General American is the English accent which considered as standard in North America and heard mostly in American film, shows, news or series. It is considered more familiar to hear globally; 3) The General Australian is English spoken in Australia. British and American English are standard English pronunciation that is widely used. British and American English have significant differences of pronunciation. The pronunciation sound noticeably different 
(Wakelin, 2008). For example, the most obvious is the way ' $r$ ' is pronounced. In American English ' $r$ ' is pronounced quite clearly but in British English ' $r$ ' which comes after a vowel in the same syllable (e.g. car, hard, market), the ' $r$ ' is not pronounced. There are some differences which are difficult and confusing. Phonetic symbol or IPA symbols helps to ensure accuracy because it is a standard in sound description. By using IPA symbols, the differences between British and American English can be summarized as follows (Gomez, 2009).

Formulation of the problem on this research that students did not pay attention to the use of vocabularies when they are writing. The use and choice of words that students use are not the focus when writing. So students didn't really understand where British English and American English are. This study analyzed data on the use of British and American English on writing skills on the Instagram accounts of students at Nahdlatul Ulama Purwokerto University

\section{METHOD}

This study uses a qualitative descriptive approach so that it emphasizes more words. According to (Lindlof and Taylor, 2002), this research is fundamentally seeking truth and analyze the circumstances, content, and experience of social action, rather than transforming it into a mathematical or other formal transformation. Researchers used purposive sampling, namely taking a sample of the Instagram account of students at the Nahdlatul Ulama University of Purwokerto. Accounts analyzed as data were 50 Instagram accounts containing English captions (English writing) in English classes with hastag \#learningenglishwithmrsade. As the data, the researchers took 50 samples of Instagram accounts of students at Nahdlatul Ulama University Purwokerto. Researchers analyzed and classified British English and American English in the caption on the
Instagram account of the Purwokerto Nahdlatul Ulama University Students.

\section{FINDINGS}

Regarding with the purposes of this research, the researchers classified the British English and American English vocabularies that were used by students of the Nahdlatul Ulama University of Purwokerto in developing writing skills on their Instagram accounts.. The researchers captured 50 captions on the 50 accounts as the data.

\section{iqbal.riyanto. 92 Hil I want to introduce my self My name is likbal Riyanto \\ You can call me Ikba \\ I com from Cilacap \\ I was born on May 26 1999. I am 20 yeard old \\ I am live in karang klesem \\ I have 1 sister \\ My hobby is playing football \\ Laike: I love playing football because by playing football I can \\ know that life needs someone else \\ Dis laike: I dont like bitter melon,because bitter melon is like a promise you have broken bitter \\ \#adenicia \\ \#̈unupurwokerto \\ \#learningenglishwithmrsade \\ Octaber 11,2014 \\ Figure 1. Instagram Caption of Iqbal.riyanto.92}




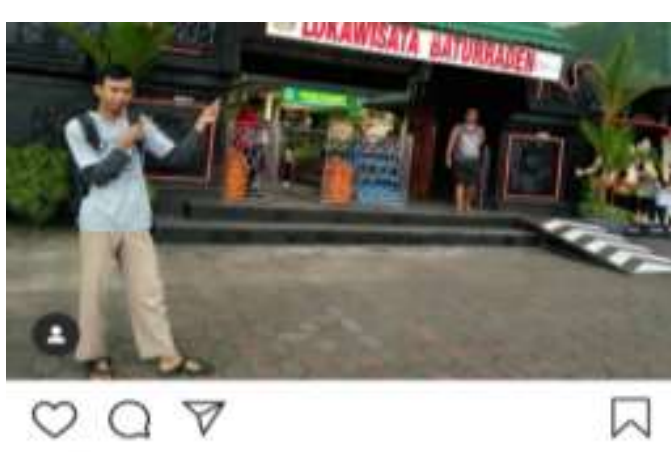

44 likes

danang dif 17 One of the tourist attractions that must be wiaited while in Purwokerto is Baturraden Touriam. Baturraden Tourism Object is currently one of the tourist locations in the Faturraden District, Hanyumas Regency, which has the mosit complete facilities. The location is also quite close to the center of Purwokerto, only around $15 \mathrm{KM}$ about 15 minutes away by motorized vehicie. This tourist spot is suitabie for all ages from children to adults with various facilities

Weamingengliahwithmrsade wunupurwokerts \#majormathematic

Figure 2. Istagram Caption of danang_dj17

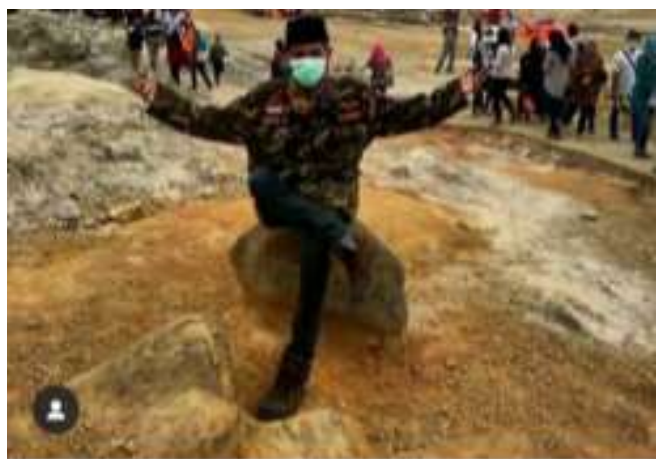

\section{$\bigcirc \bigcirc \nabla$}

21 likes

etuslank Helio, my name is Restu Pratomo from the Management Study Program at Nahdlatul Uama University. Purwokerto. I will describe the nature of the dieng crater crater. Dieng is a plateau in Central Java that is included in the Banjarnegara Regency and Wonosobo Regencies. Dieng is the most beeutiful tourist spot in Central Java. The sikidang dieng crater is an active volcanic region and can be said to be a giant volcano. Even so, the Dieng Plateau actually has its own charm. Come and enjoy the natural charm of Dieng. alearningenglishwithmrsade

aProdi_Manajemen_Mata_Kuliah_Bahasa_Inggris aunupurwokerte

madenicia

Figure 3. Instagram caption of etuslank
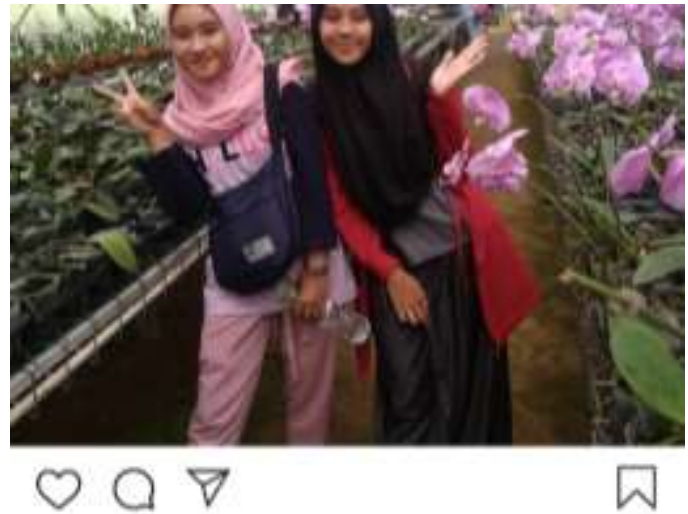

40 likes

asfiyah27 Last weekend, my friend and I went to Sekar Gumilang orchid garden.

The location in ketenger village, Baturraden.

There are many kind of orehid.

We can saw and buy some beeutiful orchid. Besaid that we

also can saw euitivation of orchid.

So, i very enjoy in there.

its very suitable for orchid lowern?

Wiearningenglishwithmreade.nicis Hunupurwokerto

Nprodiagroteknologinonreguler

Figure 4. Instagram caption of asfiyah27

From the process of data analysis, we can look the findings;

1. Classification of British English and American English

1.1. Differences of Lexicon

1.2. Differences of Spelling

1.3. Pronunciation

2. Writing Skill

2.1. Grammatical Differences in British and American English

2.2. The Using of Grammatical British English and American English on Caption Writing

3. As a Knowledge Reference of British English and American English

3.1. Instagram As a Popular Media for Writing Development

3.2. Glossary

\section{DISCUSSION}

1. Classification of British English and American English 


\subsection{Differences of Lexicon}

Fares (2019) writes lexicon or vocabulary is a central linguistic area where there are noticeable differences between British English and American English.

Therefore, we see that the historical separation of England and the United States contributed to the discrepancy or independent quality of vocabulary in British English and American English, at least in the areas of food, clothing and transportation items. The following tables show some examples regarding the differences in vocabulary between British English and American English. There is a variety of usage for vocabulary items in both British English and American English. In other words, some words are there in both varieties of English, but they are used in different contexts by people in the United States and Britain. A good example is the word "mad," which is mostly American, while "angry" is British. Even though, Americans use "angry" in formal contexts, often under the impression that "mad" as a synonym is incorrect. On the other hand, many speakers of British English use "mad"in the sense of being "angry," as it was usually used in Old English, meaning "dissatisfied" with a certain aspect, not,for example, "crazy."

Table 1. Differences of Lexicon/Vocabulary

\begin{tabular}{|l|c|l|c|}
\hline \multicolumn{1}{|c|}{$\begin{array}{c}\text { BrE } \\
\text { Vocabulary }\end{array}$} & Number of Account & \multicolumn{1}{c|}{$\begin{array}{c}\text { AmE } \\
\text { Vocabulary }\end{array}$} & Number of Account \\
\hline Holiday & 2 & Vacation & 3 \\
\hline Football & 2 & Soccer & - \\
\hline Garden & 2 & Yard & - \\
\hline Organisation & - & Organization & 1 \\
\hline Car Park & - & Parking lot & 2 \\
\hline Programme & - & Program & 3 \\
\hline Mate & - & Friend & 2 \\
\hline Sort & - & Kind & 1 \\
\hline Mobile Phone & - & Cell Phone & 1 \\
\hline Having a bath & - & Taking a bath & \\
\hline Forwards & - & Forward & 1 \\
\hline Motorway & - & Highway & 1 \\
\hline Total of Account & $\mathbf{6}$ & $\begin{array}{l}\text { Total } \\
\text { Account }\end{array}$ & $\mathbf{1 3}$ \\
\hline
\end{tabular}

According of the table that 13 accounts used American English lexicon and 6 accounts used British English Lexicon.
1.2. Differences of Spelling

There are many differences in spelling in British English and 
American English. This difference can be seen from the following aspects.

\subsection{1. (o) versus (ou)}

American spelling prefers (o) before (r) and (1) inwords, while British prefers (ou). For instance, in American English we find "honor, favor and molt" whereas in British English we find "honour, favour and moult."

According to Richard Vensky (2001), this contrast in spelling between British English and American English is dated to the American Revolution, and particularly to the spelling reform lead by the American linguist Noah Webster.

According to the explanation written by Richard Vensky that the contrast in spelling between British English and American English stems from Revolutionary American, and in particular the spelling reforms led by American linguist Noah Webster.

Menganti Beach tourism is one of favorite vacation in Karang Duwur Village, Ayah District, Kebumen Regency, Central Java. The panorama that can be witnessed from Tanjung Karangbata is indeed so charming. The towering cliffs that stretch on edge of the sea create an atmosphere like in New Zealand. So, when you visit Kebumen, don't forget to visit the beach to replace. See you at Kebumen”. (septianto250196gm)
Based on the difference in spelling (o) vs (ou), the researcher found 1 word that writing captions by spelling American English on the student's Instagram account @ septianto250196gm is the word 65 | >> "favorite". “

\subsection{2. (-re) versus (-er)}

In British English it prefers the suffix (-re) as in the word "centre, fibre and metre while in American English it prefers the suffix (-er) as in the word" center, fiber, meter ".

On the Instagram account of the Nahdlatul Ulama University of Purwokerto students, there is one word with spelling American English on the account belonging to @ danang_dj17, namely the word 'center'.

"One of the tourist attractions that must be visited while in Purwokerto is Baturraden Tourism. Baturraden Tourism Object is currently one of the tourist locations in the baturraden District, Banyumas Regency, which has the most complete facilities. The location is also quite close to the center of Purwokerto, only around 15KM, about 15 minutes away by motorized vehicle. This tourist spot is suitable for all ages from children to adults with various facilities”.(@danang_dj17)

\subsubsection{Doubling final consonants}

We can look the differences of British English and American 
English from doubling final consonants.

Fares, A.A.F.M.A. (2019) states there is a difference between British English and American English spelling in the handling of final (1) before suffixes. Before (ment) and (ful), American English spelling doubles or keeps a doubled (1) as in "enrollment, fulfillment,skillful and willful." On the other hand, the British prefer to double a final (l), even if the final syllable is not stressed, while Americans generally double a final consonant only, as in "traveling"

and "marvelous" versus British "travelling" and "marvellous".

In the research written by Fares, it is explained that there is a difference between the spelling of British English and American English in the suffix (l) before the suffix. Before (ment) and (ful), in American English there is a double (1) as in "enrollment, fulfillment, skillful and willful" In contrast, English prefers to double the final (1), even if the last syllable is not stressed, while people Americans generally only double the final consonants, as in "traveling" and "marvelous" versus the British English "travelling" and "marvellous".

Based on the explanation from Fares, the researcher found a caption with British English spelling on the @ nhafifah22 student's Instagram account, namely the word "travelling".
"Hello guys. In this opportunity, I want to introduce my self. My name is Nur Hafifah. You can call me Ifah. I come from Purwokerto. I was born in Banyumas, on November 8th 2000. I am 18 years old. I have a brother, his name is Jumadi. My hobby is travelling. My future is an Ambassador of Saudi Arabia. My motto is "Thalabul 'ilmi as a soothing and conditioning heart”. I think enough, thanks for your attention"(@nhafifah22)

\subsection{Pronunciation}

Spoken English has wide variation in pronunciation (Wakelin, 2008) There are 3 Standard English pronunciations are distinguished and spoken. 1) The Received Pronunciation, called Oxford English, is the standard of British English; 2) The General American is the English accent which considered as standard in North America and heard mostly in American film, shows, news or series. It is considered more familiar to hear globally; 3) The General Australian is English spoken in Australia. British and American English are standard English pronunciation that is widely used. British and American English have significant differences of pronunciation. The pronunciation sound noticeably different. For example, the most obvious is the way ' $r$ ' is pronounced. In American English ' $r$ ' is pronounced quite clearly but in British English ' $r$ ' which comes after a vowel in the same syllable (e.g. car, hard, market), the ' $r$ ' is not pronounced. There are some differences which are difficult and confusing. Phonetic symbol or IPA symbols helps to ensure accuracy because it is a standard in sound description. By using IPA symbols, the differences between British and 
American English can be summarized as follows (Gomez, 2009).

1. Differences in vowel pronunciation The most relevant ones are the change of diphthong [əซ], change of [p], change of [æ], and change of [ju:].

2. Differences in consonant pronunciationIt involves the difference pronunciation of letter $t$

3. Change of stress

It is the change of stress in certain suffixes such as -ate, -atory

4. Differences in articulation American English has a clear tendency to pronounce unstressed syllables, while British English does not show it.

\section{Writing Skill}

\subsection{Grammatical Differences in British and American English}

There are many grammatical differences in detailed aspect of British and American English. In some structures, they use different grammatical form to express same meaning; they also use integrated grammatical form while other adopts the omitted form. However, overall here is no judgment where it is better or advanced. Bin Zhang (Asian Social Science, 2008) classified some types of grammatical differences in American and British English. The researcher took those theories to analyze the finding of Instagram captions which had been written by students of Nahdlatul Ulama University below.

\subsubsection{Differences in Verbs}

a. In British English, the past tense of "get" is "got" while American English usually uses past participle "eaten". When Americans use "got", they mean "own, possess and dominate." For example, "They have got no pride."

b. British English uses "Have you any children?" or "Have you got any
In the research, because we focus on the writing skill of IG caption, the researcher used phonetic symbol (IPA symbols) to analyze. The words are analyzed by using phonetic IPA symbols based on the differences of IPA symbols in American and British English. It showed noticeably how different the phonetic symbol is in both.

The result of analysis about phonetic symbol from 50 accounts showed 55 words with the phonetic symbols. The phonetic symbols was classified between $\mathrm{BrE}$ and AmE.

children?" and Americans commonly expresses with "Do you have any children?"

\subsubsection{Differences in Prepositions}

Differences between British and American English in preposition are shown in the following two aspects:

a. Different use of prepositions in the construction of phrases

My son's name stands first in the list. $(\mathrm{BrE})$

My son's name stands first on the list. (AmE)

b. Omitting preposition

In British English, before "day", "week", or "certain day", preposition "on" shall be used, while American English is not.

The new semester starts on August. (BrE)

The new semester starts August. (AmE)

In American English, when "home" is used as adverb, it does not use the preposition "at". However, in British English, they use "at home".

Is he home?(AmE)

Is he at home?(BrE) 


\subsubsection{Differences in Tense}

There are differences in the use of tense in British and American English when it is expressing the event that just happened. British English uses past perfect tense, such

$\ll \mid 68$ as "I have just eaten your brownies cake" or "I have just taken your gift". However American English adopts past tense such as "I just ate your brownies cake" or "I just took your gift."

\subsubsection{Differences in Use of Subjunctive Mood}

In subjunctive mood, American English will reserve traditional subjunctive words. For xample:

I suggest that event should be postponed. (AmE)

I suggest that event be postponed. $(\mathrm{BrE})$

However, British English will include "should" in subordinate clause in non-formal and non-law English.

I insist that you go. (AmE)

I insist that you should go. (BrE)

\subsubsection{Differences in Use of Noun}

a. Differences in Forms

$\begin{array}{ll}\text { BrE } & \text { AmE } \\ \text { Candidature } & \text { Candidacy } \\ \text { Centenary } & \text { Centennial } \\ \text { Cookery (book) } & \text { Cook (book) } \\ \text { Racialist, } & \text { Racist, Racism } \\ \text { Racialism } & \\ \text { Sparking Plug } & \text { Spark Plug } \\ \text { Transport } & \text { Transportation }\end{array}$

\section{b. Same Word, Different Meanings}

There are two types in this classification. The first one is to add meanings. When Americans want to express a new thing or object, it seems to them that the most convenient method is to add a new meaning to one existing word. For example:
Clout refers to power, influence of prestige, especially in politics.

Family means one of the operational unit of the mafia

Point indicates a charge of fee discounted by lender from a loan, by the effective interest rate if increased

The other is to change the meaning. Many words that originate from the UK now possess a totally different meaning in US.

\section{Words}

Bill

Billion

Guy

Pressman

Public school

\section{c. Same Meaning, Different Word} expressing certain object, thing or concept in British and American English.

\section{AmE \\ BrE}

Bar

Can (as a can of soup)

Candy

Cookie

Cracker

Long distance call

Package

Intersection

Railroad

Subway

Superhighway,

speedway
Public house, pub

Tin

Sweets

Sweet biscuit, small cake

Biscuit (dry)

Trunk call

Parcel

Junction, crossroads

Railway

Tube, underground

Motorway
There are different words which are used in

\subsubsection{Differences in Articles}

\section{a. The Omitting of Articles}

Most phrases of British English have articles, while American English do not have the articles. "The" in the standard of expression in British English "all the afternoon", "all the winter", "all the week" are usually omitted in American English. For example, "my dad works 
all week" or "he rides his new car all afternoon."

British English also uses article in front of sickness or river, such as the measles, the flu, the Niagara Falls, the Black river. It is different with American English which does not use the articles to those. However, there are exceptions where British English does not use and American English uses.

\section{BrE}

AmE

Go into hospital Go into the hospital

In hospital At university In the hospital At the university

Other examples are as follows:

Next day, the class began. (BrE)

The next day, the class began. (AmE)

In future, I'd like to invite you. (BrE)

In the future, I'd like to invite you. (AmE)

c. The position of articles

British English and American English have different position of articles. In the use of " $a$ " or "an" with "half" in British English is " $a$ " follows "half", for example "half a dozen", "half an hour", "half a pound." While American English puts " $a$ " in front of "half", for example, "a half dozen", "a half hour."

\subsubsection{Differences in Pronouns}

British and American English use different pronouns to repeat the indefinite pronoun "one". British English uses "one" for example, "One cannot succeed unless one tries hard". While American uses "he" for example, "One cannot succeed unless he tries hard."

\subsubsection{Differences in Adjectives and Adverbs}

a. In non-formal American English adjectives can be used as adverbs, for example "a real good meal." However, in British English and formal American English only adverbs can be used "a really good meal."

b. In American English, adverbs can be used more feely in respect of position. They can either be placed in front of auxiliary verbs or behind them, while the meaning of the sentences remains same. For example, "the $y$ never will agree with your opinion" or "they will never agree with your opinion." However, in British English the position of adverbs placed behind the first auxiliary verb.

c. In British English, the adverbs "yet" and "already" cannot be used in past tense and can only be used in past perfect tense. However, in American English, they can be used in both. For example

I haven't bought the books yet. (AmE, BrE)

I didn't buy the book yet. (AmE)

\subsection{The Using of Grammatical British English and American English on Caption Writing}

There are grammatical differences of American and British English that found on Instagram captions. In the analysis, there are 3 types grammatical differences found; the difference in use of noun, difference in adverb and difference in articles. In first type, the noun is categorized for having same meaning but different word. The account @idah.lestarii uses American style by using common noun which American usually uses. The user wrote "package", instead of "parcel". 
While another finding is shown in second type, it has difference in the use of adverb "yet. The use of "yet" in the caption refers to the use American English grammatical because the adverb "yet" can be used not only in past perfect tense but also in past tense. It is different with British English which only used in past perfect tense. In the account@ @ririetz, it is written "This Pereng tour was recently built and is not yet 100\% finished." The using of "yet" in past tense reflected American English.

The difference in adverb is also found in the position of adverb itself. In the caption of @asfiyah27 it uses American English by looking from the position of adverb. It is written "we also can saw cultivation". Adverb "also" is placed before auxiliary verb. In American English, adverb can be used more freely in the position. Adverb can be either placed in front of auxiliary verb or behind them, while meaning remains same. On the contrary, In British English, it is mostly placed after the auxiliary verb.

The last type of grammatical differences is differences in article. The use of British English in the use of article "the" found in @etuslank @didi_habibii_2818 and @ bachtiar1597. Three accounts used the addition of article "the" in the name of river, mountain and waterfall. "The" can be used in geographical location like mountain, island, river, waterfall but not all use it. Commonly British English style puts article "the" in front of the name of geographical location. In the caption of account @etuslank said "I will describe the nature of the Dieng Crater."@didi_habibii_2818 also wrote in his caption "don't forget to stop by the Biul waterfall." The use of "the" in "the Dieng Crater' and "the Biul Waterfall" shows that they use British English. American English will omit "the" and use "Dieng Crater" and "Biul Waterfall" instead. The account @ bachtiar1597 also put article "the" in front of name of river "Bendung Gerak Serayu is a dam for the Serayu river." These three accounts clearly reflected the use of British English in their captions.
As far as the differences of British and American English are concerned to English learners. Although both share the same sources and items but they still have grammatical differences. However, these differences are not so fundamental in learning activity. But the students do need to have comprehension about British and American English. English teachers should explain more about the grammatical differences to the students. The differences of grammatical in British and American English sometime lead to the confusion for students or English learners because the books or teachers do not give special characteristic which style is used. The differences should not be obstacle to learn English since both are formal and correct to use. In English teaching, the teachers should guide students more to know the differences and encourage them to write exactly one style in writing.

\section{As a Knowledge Reference of British English and American English 3.1.Instagram As a Popular Media for Writing Development}

Instagram is one of greatest social media which has big popularity around the world. Instagram has reached millions users who upload million photos in the platform. According to Press Page, instagram has more than 200 million users, 20 billion photos with an average of 1.6 billion likes a day. Instagram is gaining popularity quicker than facebook. This popularity is possibly because of many famous figures like Barack Obama, Oprah Winfey, Beyonce and also Kpop artists have their active instagram as well (Lunden, 2014). Sharing pictures and videos become one of top three most common usages of social for students's attitudes. Those activities 
are clearly one of Instagram's basic features. These features are useful because instagram offer visual element for learning media (Mao, 2014).

Teacher can use instagram in classroom to assist in creating community of learners, to give room for students to communicate and socialize. By using the caption, like and comment features, the students can learn to improve their writing skill in English beyond classrooms. In digital era, teaching and learning English today is not just about class activities. The use of social media in learning English helps students to develop their language skills, especially for young people who have become technology addicts. Instagram becomes a learning media which students can be immersed and accustomed to. The young learner's familiarity with Instagram can give an advantage because it makes student fun and less stress to learn (McBride, 2009).
Instagram indeed has received a lot of attention from students, as well as Nahdlatul Ulama University's students. In teaching activity, instagram is used as learning media to practice writing skill. The teacher gave activity to upload and write English caption to describe the picture. From those activities, the writing skill can be assessed and the feedback can be given to each student. The captions actually show some results of the use of British and American English. There are findings about differences of British and American English in their writing. Based on the findings, the students mostly use American English in their writing. It possibly comes from the influence of American popular culture which spread in social media and popular digital platforms. American culture easily crafted many contents and shows in their daily surfing on the internet.

\subsection{Glossary}

Table 2. Glossary

\begin{tabular}{|c|c|c|c|c|}
\hline \multirow{2}{*}{ No } & \multicolumn{2}{|c|}{ Vocabulary } & \multirow[b]{2}{*}{ Definition } & \multirow[b]{2}{*}{ Meaning } \\
\hline & British English & American English & & \\
\hline 1 & $\begin{array}{c}\text { Air } \\
\text { BrE/eə/ } \\
\mathrm{AmE} / \varepsilon r /\end{array}$ & $\begin{array}{c}\text { Air } \\
\text { BrE/eə/ } \\
\text { AmE/cr/ }\end{array}$ & $\begin{array}{l}\text { N. The mixture of } \\
\text { gases that surrounds } \\
\text { the earth and the } \\
\text { people }\end{array}$ & Udara \\
\hline 2 & $\begin{array}{c}\text { Binder } \\
\text { Bre /baində/ } \\
\text { AmE/baindər/ }\end{array}$ & $\begin{array}{c}\text { Binder } \\
\text { Bre /baində/ } \\
\text { AmE/baindər/ }\end{array}$ & $\begin{array}{l}\text { N. hard cover for } \\
\text { holding sheets of } \\
\text { paper, magazines, etc. } \\
\text { together }\end{array}$ & Bahan Pengikat \\
\hline 3 & $\begin{array}{c}\text { Boat } \\
\text { BrE/bəot/ } \\
\text { AmE/bovt/ }\end{array}$ & $\begin{array}{c}\text { Boat } \\
\text { BrE/bəøt/ } \\
\text { AmE/bovt/ }\end{array}$ & $\begin{array}{l}\text { N. A small vehicle that } \\
\text { is used for travelling } \\
\text { across water }\end{array}$ & Perahu \\
\hline 4 & $\begin{array}{c}\text { Born } \\
\text { BrE/bo:n/ } \\
\text { AmE/born/ }\end{array}$ & $\begin{array}{l}\text { Born } \\
\text { BrE/bo:n/ } \\
\text { AmE/born/ }\end{array}$ & $\begin{array}{l}\text { V. used only in the } \\
\text { passive, without by. to } \\
\text { come out of your } \\
\text { mother's body at the } \\
\text { beginning of your life } \\
\text { Adj. having a natural } \\
\text { ability or skill for a } \\
\text { particular activity or } \\
\text { job }\end{array}$ & Lahir \\
\hline 5 & $\begin{array}{c}\text { Car park } \\
\text { BrE/'ka: pa:k/ } \\
\text { AmE/'ka:r pa:rk/ }\end{array}$ & $\begin{array}{c}\text { Parking lot } \\
\text { BrE/'pa:kin lpt/ } \\
\text { AmE/'pa:kin lot/ }\end{array}$ & $\begin{array}{l}\text { N. an area or a } \\
\text { building where people } \\
\text { can leave their cars }\end{array}$ & Tempat Parkir \\
\hline
\end{tabular}




\begin{tabular}{|c|c|c|c|c|}
\hline \multirow{2}{*}{ No } & \multicolumn{2}{|c|}{ Vocabulary } & \multirow[b]{2}{*}{ Definition } & \multirow[b]{2}{*}{ Meaning } \\
\hline & British English & American English & & \\
\hline 6 & $\begin{array}{c}\text { Centre } \\
\text { BrE/scntə/ } \\
\text { AmE/scntər/ }\end{array}$ & $\begin{array}{c}\text { Center } \\
\mathrm{BrE} / \mathrm{s} \varepsilon n t ə / \\
\mathrm{AmE} / \mathrm{s} \varepsilon n t ə r /\end{array}$ & $\begin{array}{l}\text { N. the middle point or } \\
\text { part of something } \\
\text { V. [intransitive, } \\
\text { transitive] to be the } \\
\text { person or thing around } \\
\text { which most activity } \\
\text { takes place; to make } \\
\text { somebody/something } \\
\text { the central person or } \\
\text { thing }\end{array}$ & Pusat \\
\hline 7 & $\begin{array}{c}\text { Crater } \\
\text { BrE/'kreitə/ } \\
\text { AmE/'kreitər/ }\end{array}$ & $\begin{array}{c}\text { Crater } \\
\text { BrE/'kreitə/ } \\
\text { AmE/'kreitər/ }\end{array}$ & $\begin{array}{l}\text { N. a large hole in the } \\
\text { top of a volcano. }\end{array}$ & Kawah \\
\hline 8 & $\begin{array}{c}\text { Entre } \\
\text { BrE/\&ntə/ } \\
\text { AmE/'Entər/ } \\
\end{array}$ & $\begin{array}{c}\text { Enter } \\
\text { BrE/\&ntə/ } \\
\text { AmE/'Entər/ }\end{array}$ & $\begin{array}{l}\text { V. To come or go into } \\
\text { a place }\end{array}$ & Masuk \\
\hline 9 & $\begin{array}{c}\text { Entrepreneur } \\
\text { BrE,/pntrəprə'nз:/ } \\
\text { AmE/pntrəprə'nзr/ }\end{array}$ & $\begin{array}{c}\text { Entrepreneur } \\
\text { BrE,/pntrəprə'nз:/ } \\
\text { AmE/pntrəprə'nзr/ }\end{array}$ & $\begin{array}{l}\text { N. a person who } \\
\text { makes money by } \\
\text { starting or running } \\
\text { businesses, especially } \\
\text { when this involves } \\
\text { taking financial risks }\end{array}$ & Pengusaha \\
\hline 10 & $\begin{array}{c}\text { Fall } \\
\text { BrE/fo:1/ } \\
\text { AmE/fo:1/ }\end{array}$ & $\begin{array}{c}\text { Fall } \\
\text { BrE/fo:1/ } \\
\text { AmE/fo:1/ }\end{array}$ & $\begin{array}{l}\text { V. An act of falling } \\
\text { down }\end{array}$ & Jatuh \\
\hline 11 & $\begin{array}{c}\text { Football } \\
\text { BrE/futbo:1/ } \\
\text { AmE/fut, bol/ }\end{array}$ & $\begin{array}{c}\text { Soccer } \\
\text { Bre/'spkə(r)/ } \\
\text { AmE/'sa:kər/ }\end{array}$ & $\begin{array}{l}\text { N. a game played by } \\
\text { two teams of } 11 \\
\text { players, using a round } \\
\text { ball which players kick } \\
\text { up and down the } \\
\text { playing field. Teams } \\
\text { try to kick the ball into } \\
\text { the other team's goal. }\end{array}$ & SepakBola \\
\hline 12 & $\begin{array}{c}\text { Forest } \\
\text { BrE/' forist/ } \\
\text { AmE/'forəst/ }\end{array}$ & $\begin{array}{c}\text { Forest } \\
\text { BrE/' forist/ } \\
\text { AmE/' forəst/ }\end{array}$ & $\begin{array}{l}\text { N. a large area of land } \\
\text { that is thickly covered } \\
\text { with trees }\end{array}$ & Hutan \\
\hline 13 & $\begin{array}{c}\text { Forwards } \\
\text { BrE/' fo: wəd// } \\
\text { AmE/' forwərd }\end{array}$ & $\begin{array}{c}\text { Forward } \\
\text { BrE/' fo:wəd/ } \\
\text { AmE/' forwərd/ }\end{array}$ & $\begin{array}{l}\text { Adv. In the direction } \\
\text { that is in the front of } \\
\text { you }\end{array}$ & Maju \\
\hline 14 & $\begin{array}{c}\text { Garden } \\
\text { BrE/ga:dn/ } \\
\text { AmE/gardən/ }\end{array}$ & $\begin{array}{c}\text { Yard } \\
\text { BrE/ja:d/ } \\
\text { AmE /ja:rd/ }\end{array}$ & $\begin{array}{l}\text { N. a piece of land next } \\
\text { to or around your } \\
\text { house where you can } \\
\text { grow flowers, fruit, } \\
\text { vegetables, etc. }\end{array}$ & Taman/Halaman \\
\hline 15 & $\begin{array}{c}\text { God } \\
\text { BrE/gnd/ } \\
\text { AmE/gad/ }\end{array}$ & $\begin{array}{c}\text { God } \\
\text { BrE/gnd/ } \\
\text { AmE/gad/ }\end{array}$ & $\begin{array}{l}\text { N. The being or spirit } \\
\text { Christianity, Islam, } \\
\text { and Judaism who } \\
\text { people say prayers to } \\
\text { and who people } \\
\text { believe created and } \\
\text { universe }\end{array}$ & Tuhan \\
\hline
\end{tabular}




\begin{tabular}{|c|c|c|c|c|}
\hline \multirow{2}{*}{ No } & \multicolumn{2}{|c|}{ Vocabulary } & \multirow[b]{2}{*}{ Definition } & \multirow[b]{2}{*}{ Meaning } \\
\hline & British English & American English & & \\
\hline 16 & $\begin{array}{c}\text { Gone } \\
\text { BrE/gnn/ } \\
\text { AmE/gon/ }\end{array}$ & $\begin{array}{c}\text { Gone } \\
\text { BrE/gpn/ } \\
\text { AmE/gon/ }\end{array}$ & $\begin{array}{l}\text { V. To move or travel } \\
\text { from one place to } \\
\text { another }\end{array}$ & Pergi \\
\hline 17 & Having a bath & $\begin{array}{c}\text { Taking a bath } \\
\text { BrE/'terkın ə ba: } \theta / \\
\text { AmE/'terkin ə bæ } \theta /\end{array}$ & $\begin{array}{l}\text { V. Clean the whole } \\
\text { body }\end{array}$ & Mandi \\
\hline 18 & $\begin{array}{c}\text { Holiday } \\
\text { BrE/'holədeI/ } \\
\text { AmE/'ha:lədeI/ }\end{array}$ & $\begin{array}{c}\text { Vacation } \\
\text { BrE/və'keIfən/ } \\
\text { AmE/ver'keıJən/ }\end{array}$ & $\begin{array}{l}\text { N. a period of time } \\
\text { when you are not at } \\
\text { work or school. } \\
\text { [uncountable, } \\
\text { countable] a period of } \\
\text { time spent travelling or } \\
\text { 19resting away from } \\
\text { home }\end{array}$ & Libur/Liburan \\
\hline 19 & $\begin{array}{c}\text { Horse } \\
\text { AmE/hors/ } \\
\text { BrE/ho:s/ }\end{array}$ & $\begin{array}{c}\text { Horse } \\
\text { AmE/hors/ } \\
\text { BrE/ho:s/ }\end{array}$ & $\begin{array}{l}\text { N. a large animal with } \\
\text { four legs, a mane (= } \\
\text { long thick hair on its } \\
\text { neck) and a tail. } \\
\text { Horses are used for } \\
\text { riding on, pulling } \\
\text { carriages, etc. }\end{array}$ & Kuda \\
\hline 20 & $\begin{array}{l}\text { Mate } \\
\text { BrE/meit/ } \\
\text { AmE/meit/ }\end{array}$ & $\begin{array}{l}\text { Friend } \\
\text { BrE/frend/ } \\
\text { AmE/frend/ }\end{array}$ & $\begin{array}{l}\text { N. a person you know } \\
\text { well and like, and who } \\
\text { is not usually a } \\
\text { member of your family }\end{array}$ & Teman \\
\hline 21 & $\begin{array}{c}\text { Mobile Phone } \\
\text { BrE/məubarl 'fəun/ } \\
\text { AmE /,məobl ' fəun/ }\end{array}$ & $\begin{array}{c}\text { Cell Phone } \\
\text { BrE/'scl, forn/ } \\
\text { AmE/'sclfoun/ }\end{array}$ & $\begin{array}{l}\text { N. A small phone that } \\
\text { you can carry around } \\
\text { with you }\end{array}$ & Telepon genggam \\
\hline 22 & $\begin{array}{c}\text { Motorway } \\
\text { BrE/'məðtəweı/ } \\
\text { AmE /'məotərwes/ }\end{array}$ & $\begin{array}{c}\text { Highway } \\
\mathrm{BrE} / \text { ' haiwei/ } \\
\text { AmE/' hawweI/ }\end{array}$ & $\begin{array}{l}\text { N. A wide road where } \\
\text { traffic can travel fast } \\
\text { for long distance } \\
\text { between large towns }\end{array}$ & Jalan raya \\
\hline 23 & $\begin{array}{c}\text { Nature } \\
\text { BrE/'nertə/ } \\
\text { AmE/'nertfər/ }\end{array}$ & $\begin{array}{c}\text { Nature } \\
\text { BrE/'nertə/ } \\
\text { AmE/'nertfər/ }\end{array}$ & $\begin{array}{l}\text { N. all the plants, } \\
\text { animals and things that } \\
\text { exist in the universe } \\
\text { that are not made by } \\
\text { people }\end{array}$ & Alami \\
\hline 24 & $\begin{array}{c}\text { Old } \\
\text { BrE/ould/ } \\
\text { AmE/ould/ }\end{array}$ & $\begin{array}{c}\text { Old } \\
\text { BrE/əold/ } \\
\text { AmE/ould/ }\end{array}$ & Adj. A particular age & Tua \\
\hline 25 & $\begin{array}{c}\text { Orchid } \\
\text { BrE/' o:kid/ } \\
\text { AmE/'orkəd/ }\end{array}$ & $\begin{array}{c}\text { Orchid } \\
\text { BrE/'っ:kId/ } \\
\text { AmE/'orkəd/ }\end{array}$ & $\begin{array}{l}\text { N. a plant with } \\
\text { brightly coloured } \\
\text { flowers of unusual } \\
\text { shapes. There are } \\
\text { many different types } \\
\text { of orchid and some of } \\
\text { them are very rare. }\end{array}$ & Anggrek \\
\hline
\end{tabular}




\begin{tabular}{|c|c|c|c|c|}
\hline \multirow{2}{*}{ No } & \multicolumn{2}{|c|}{ Vocabulary } & \multirow[b]{2}{*}{ Definition } & \multirow[b]{2}{*}{ Meaning } \\
\hline & British English & American English & & \\
\hline 26 & 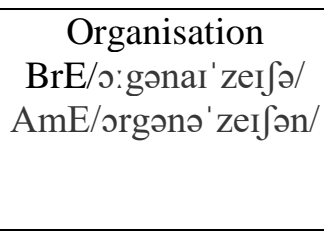 & $\begin{array}{c}\text { Organization } \\
\text { BrE/s:gənaI zeIfə/ } \\
\text { AmE/orgənə'zeIfən/ }\end{array}$ & $\begin{array}{l}\text { N. a group of people } \\
\text { who form a business, } \\
\text { club, etc. together in } \\
\text { order to achieve a } \\
\text { particular aim }\end{array}$ & Organisasi \\
\hline 27 & $\begin{array}{c}\text { Park } \\
\text { BrE/pa:k/ } \\
\text { AmE/park/ }\end{array}$ & $\begin{array}{c}\text { Park } \\
\text { BrE/pa:k/ } \\
\text { AmE/park/ }\end{array}$ & $\begin{array}{l}\text { N. An open area in a } \\
\text { town, often with grass } \\
\text { or tress, where people } \\
\text { can go to walk, play, } \\
\text { etc. }\end{array}$ & Taman \\
\hline 28 & $\begin{array}{c}\text { Partner } \\
\text { BrE/'pa:tnə/ } \\
\text { AmE/'partnər/ }\end{array}$ & $\begin{array}{c}\text { Partner } \\
\text { BrE/'pa:tnə/ } \\
\text { AmE/'partnər/ }\end{array}$ & $\begin{array}{l}\mathrm{N} \text {. The person that you } \\
\text { married to or live with } \\
\text { as if you are married }\end{array}$ & Pasangan \\
\hline 29 & $\begin{array}{c}\text { Picture } \\
\text { BrE/'prktfə/ } \\
\text { AmE/'prktfər/ }\end{array}$ & $\begin{array}{c}\text { Picture } \\
\text { BrE/'prktə/ } \\
\text { AmE/'prktər/ }\end{array}$ & $\begin{array}{l}\text { N. a painting or } \\
\text { drawing, etc. that } \\
\text { shows a scene, a } \\
\text { person or thing } \\
\text { V. to imagine } \\
\text { somebody/something; } \\
\text { to create an image of } \\
\text { somebody/something } \\
\text { in your mind }\end{array}$ & Gambar/Foto \\
\hline 30 & $\begin{array}{c}\text { Programme } \\
\text { BrE/'prəogræm/ } \\
\text { AmE/'prov, græm/ }\end{array}$ & $\begin{array}{c}\text { Program } \\
\text { BrE/'prəugræm/ } \\
\text { AmE/'proひ, græm/ }\end{array}$ & $\begin{array}{l}\text { N. a set of instructions } \\
\text { in code that control the } \\
\text { operations or functions } \\
\text { of a computer }\end{array}$ & Program \\
\hline 31 & $\begin{array}{c}\text { Scenery } \\
\text { BrE/'si:nəri/ } \\
\text { AmE/'sinəri/ }\end{array}$ & $\begin{array}{l}\text { Scenery } \\
\text { BrE/'si:nəri/ } \\
\text { AmE/'sinəri/ }\end{array}$ & $\begin{array}{l}\text { N. the natural features } \\
\text { of an area, such as } \\
\text { mountains, valleys, } \\
\text { rivers and forests, } \\
\text { when you are thinking } \\
\text { about them being } \\
\text { attractive to look at } \\
\text { N. what you can see } \\
\text { from a particular place } \\
\text { or position, especially } \\
\text { beautiful countryside } \\
\text { V. to think about } \\
\text { somebody/something } \\
\text { in a particular way }\end{array}$ & Pemandangan \\
\hline 32 & $\begin{array}{c}\text { Sort } \\
\text { BrE/so:t/ } \\
\text { AmE /so:rt/ }\end{array}$ & $\begin{array}{c}\text { Kind } \\
\text { BrE/kaind/ } \\
\text { AmE/kaind/ }\end{array}$ & $\begin{array}{l}\text { N. [countable] a group } \\
\text { or type of people or } \\
\text { things that are similar } \\
\text { in a particular way. a } \\
\text { group of people or } \\
\text { things that are the } \\
\text { same in some way; a } \\
\text { particular variety or }\end{array}$ & Jenis/Macam/Baik \\
\hline
\end{tabular}




\begin{tabular}{|c|c|c|c|c|}
\hline \multirow{2}{*}{ No } & \multicolumn{2}{|c|}{ Vocabulary } & \multirow[b]{2}{*}{ Definition } & \multirow[b]{2}{*}{ Meaning } \\
\hline & British English & American English & & \\
\hline & & & type & \\
\hline 33 & $\begin{array}{c}\text { Soul } \\
\text { BrE/səol/ } \\
\text { AmE/soul/ }\end{array}$ & $\begin{array}{c}\text { Soul } \\
\text { BrE/səol/ } \\
\text { AmE/sool/ }\end{array}$ & $\begin{array}{l}\text { N. The spiritual part of } \\
\text { a person that is } \\
\text { believed to continue to } \\
\text { exist after the body is } \\
\text { dead }\end{array}$ & Jiwa \\
\hline 34 & $\begin{array}{c}\text { Sugar } \\
\text { BrE/' Juga/ } \\
\text { AmE/' Jugər/ } \\
\text { / }\end{array}$ & $\begin{array}{c}\text { Sugar } \\
\text { BrE/' Jugə/ } \\
\text { AmE/' Jugər/ }\end{array}$ & $\begin{array}{l}\text { N. A sweet substance } \\
\text { that you get from } \\
\text { certain plants }\end{array}$ & Gula \\
\hline 35 & $\begin{array}{c}\text { Tomorrow } \\
\text { BrE/ta' mbrav/ } \\
\text { AmE/ta' ma, rou/ }\end{array}$ & $\begin{array}{c}\text { Tomorrow } \\
\text { BrE/tə' mprav/ } \\
\text { AmE/tə' ma, rov/ }\end{array}$ & $\begin{array}{l}\text { N. on or during the day } \\
\text { after today }\end{array}$ & Besok \\
\hline 36 & $\begin{array}{c}\text { Tour } \\
\mathrm{BrE} / \text { toə/ } \\
\mathrm{AmE} / \mathrm{t} \text { to/ }\end{array}$ & $\begin{array}{l}\text { Tour } \\
\mathrm{BrE} / \text { toə/ } \\
\text { AmE/ toə }\end{array}$ & $\begin{array}{l}\text { V. A journey that you } \\
\text { make for pleasure } \\
\text { during you visit many } \\
\text { places. }\end{array}$ & perjalanan \\
\hline 37 & $\begin{array}{c}\text { Travelling } \\
\text { BrE/'trævlin/ } \\
\text { AmE/'trævəlin/ }\end{array}$ & $\begin{array}{c}\text { Traveling } \\
\text { BrE/'trævlin// } \\
\text { AmE/'trævəlin// }\end{array}$ & $\begin{array}{l}\text { V. To go from one } \\
\text { place to another, } \\
\text { especially over a long } \\
\text { distance }\end{array}$ & Perjalanan \\
\hline 38 & $\begin{array}{c}\text { View } \\
\text { BrE/vju:/ } \\
\text { AmE/vju:/ }\end{array}$ & $\begin{array}{c}\text { View } \\
\text { BrE/vju:/ } \\
\text { AmE/vju:/ }\end{array}$ & $\begin{array}{l}\text { N. the natural features } \\
\text { of an area, such as } \\
\text { mountains, valleys, } \\
\text { rivers and forests, } \\
\text { when you are thinking } \\
\text { about them being } \\
\text { attractive to look at } \\
\mathrm{N} \text {. what you can see } \\
\text { from a particular place } \\
\text { or position, especially } \\
\text { beautiful countryside } \\
\text { V. to think about } \\
\text { somebody/something } \\
\text { in a particular way }\end{array}$ & Pemandangan \\
\hline 39 & $\begin{array}{c}\text { Visitor } \\
\text { BrE/'vizitə/ } \\
\text { AmE/' vizətər/ }\end{array}$ & $\begin{array}{c}\text { Visitor } \\
\text { BrE/'vizitə/ } \\
\text { AmE/' vizətər/ }\end{array}$ & $\begin{array}{l}\text { N. a person who visits } \\
\text { a person or place }\end{array}$ & Pengunjung \\
\hline 40 & $\begin{array}{c}\text { Water } \\
\text { BrE/'wo:tə/ } \\
\text { AmE/'wotər/ }\end{array}$ & $\begin{array}{c}\text { Water } \\
\text { BrE/'wo:tə/ } \\
\text { AmE/'wotər/ }\end{array}$ & $\begin{array}{l}\text { N. a liquid without } \\
\text { colour, smell or taste } \\
\text { that falls as rain, is in } \\
\text { lakes, rivers and seas, } \\
\text { and is used for } \\
\text { drinking, washing, etc. } \\
\text { V. water something to } \\
\text { pour water on plants, } \\
\text { etc. }\end{array}$ & Air \\
\hline
\end{tabular}




\begin{tabular}{|c|c|c|c|c|}
\hline \multirow{2}{*}{ No } & \multicolumn{2}{|c|}{ Vocabulary } & \multirow[b]{2}{*}{ Definition } & \\
\hline & British English & American English & & Meaning \\
\hline 41 & $\begin{array}{c}\text { Waterfall } \\
\text { BrE/'wo:təfə:1/ } \\
\text { AmE/'wotər, fol/ }\end{array}$ & $\begin{array}{c}\text { Waterfall } \\
\text { BrE/'wo:təfっ:1/ } \\
\text { AmE/'wotər, fəl/ }\end{array}$ & $\begin{array}{l}\text { N. a place where a } \\
\text { stream or river falls } \\
\text { from a high place, for } \\
\text { example over a cliff or } \\
\text { rock }\end{array}$ & Air Terjun \\
\hline
\end{tabular}

\section{CONCLUSION}

Having finished discussing the subject concerning the use of British English and American English toward writing ability in Instagram, in this chapter the writers draw some conclusion in the hope that the reader of this article can clearly obtain more knowledge about British English and American English toward writing ability in Instagram.

1. The data analysis shows that some students used American English Voabulary in their writing of accounts Instagram. There are 6 accounts used in British English vocabulary and there are 13 accounts used in American English vocabulary. The classifications are: Differences of Lexicon, Differences of spelling and pronunciation.

2. In general, there are some grammatical differences written by the students in the use of British English and American English toward writing ability in Instagram. The grammatical differences in British and American English are:

a. Differences in Verbs $0 \%$

b. Differences in Prepositions 0\%

c. Differences in Tense $0 \%$ d. Differences in Use of Subjunctive Mood $0 \%$

e. Differences in Use of Noun $4 \%$

f. Differences in Articles $6 \%$

g. Differences in Pronouns $0 \%$

h. Differences in Adjectives and Adverbs $\quad 4 \%$

3. By analizing British and American English in Instagram accounts, it can be concluded that Instagram is one of the media to develop writing ability. And we can make glossary to be reference of the differences of Brtish and American English.

\section{Acknowledgments}

The researchers thanks to Ristekdikti who provide the funding of this research. And also thanks to LPPM Nahdlatul Ulama University of Purwokerto who gives information about this research. Thank you very much for students of Nahdlatul Ulama University of Purwokerto who joined in the English Class who is included as sample of 50 Instagram Accounts.

\section{REFERENCES}

Agustrianita (2017). Teachers' Perceptions Towards Social Media Use to Improve Professional Development and Integration in English Language Teaching. English Language and Literature International Conference (ELLiC). (1).17-22.

Alhabash, S., and Ma, M. (2017). A Tale of Four Platforms: Motivations and Uses of Facebook, Twitter, Instagram, and SnapchatAmong College Students? SAGE Journals, pp. 1-13

Alhabash, S., and Ma, M. (2017). A Tale of Four Platforms: Motivations and Uses of 
Facebook, Twitter, Instagram, and Snapchat Among College Students?. SAGE Journals, pp. 1-3.

Alnujaidi, S. (2017). Social Network Sites Effectiveness from EFL Students’ Viewpoints.

Anggraeni, C. W. (2017). Students' Perspectives Toward The Use of Instagram in Writing Class.

Angraeni, Candradewi Wahyu. (2017) Students' Perspective Toward The Use Of Instagram in Writing Class. 1st English Language and Literature International Conference (ELLiC), (1). Pp.68-74

Cresswell, John W. (2010). Research Design: Pendekatan Kualitatif, Kuantitatif, dan Mixed.Edisi Ketiga.Pustaka Pelajar.Yogyakarta

Denzin, N.K. dan Lincoln Y.S. (1994).

Handbook ofQualitative Research. Thosand Oaks, London, New Delhi:Sage

English Language and Literature International Conference (ELLiC). (1).68-74.

English Language Teaching, 10 (1) pp. 30-49.

Fandino, Y., J. (2013). 21st Century Skills and the English Foreign Language Classroom: A Call for More Awareness in Colombia. Gist Education and Learning Research Journal, (7), pp. 190-208.

Farez, A.A.F.M.A. (2019). British English and American English: History and Differences. International Journal of Linguistics, Literature and Translation (IJLLT) 2(1), 177-188.

Harmer, J. (2001). The Practice of English Language Teaching. London: Longman

Khusnita, Dafi. (2017). The Use of Facebook To Improve Students' Skill and Increase Their Motivation in Writing Recount Text. English Language and Literature International Conference (ELLIC. (1).75-81

Koban Koc, D., AND Koc, S. E (2016) Students' perceptions of blog use in an undergraduate linguistics course. Journal of Language and Linguistic Studies, 12(1), 9-19.

Lindlof,T.R. dan Taylor,B.C. (2002). Qualitative Communication Research Methods (second ed). Sage Publications, Thousand Oaks, CA

Lunden, I. (2014, January 21). Instagram Is The Fastest-Growing Social Site Globally, Mobile Devices Rule Over PCs For Access. TechCrunch. Retrieved July 6, 2014, (http://techcrunch.com/2014/01/21/instagram-is-the-fastest-growing-social-siteglobally-mobile-devices-rule-over-pcs-for-social-access/)

Mao, J. (2014). Social media for learning: A mixed methods study on high school students' technology affordances and perspectives. Computers in Human Behavior, 33, pp. 213-223.

McBride, K. (2009). Social-networking sites in foreign language classes: Opportunities for re-creation. The next generation: Social networking and online collaboration in foreign language learning, pp. 35-58. 
Nunan, D. (2003). Practical English Language Teaching. International Edition, McGrawHill, Singapore, 88.

Rahman, M. (2009). Approaches to Teaching Writing in Higher Education: An Enquiry from the Applied Linguistics Point of View. Stamford Journal of English. (5).166-167.

SAGE Journals 15(3), 271-291).

Uddin, M. E. (2014). Teachers' Pedagogical Belief and ITS Reflection on the Practice in Teaching Writing in EFL Tertiary Context in Bangladesh. Journal of Education and Practice, 5, 116.

Venzky, Richard L. (2001)’Spelling” The Cambridge History of the English Language. Volume IV.U.K: The Press Syndicate of the University of Cambridge.

Vie, S. (2008). Digital divide 2.0: "Generation M" and online social networking sites in the composition classroom. Computers and Composition, 25(1), pp. 9-23.

Widagdo, A. (2017). An Analysis of Writing Problems of PGSD UNNES Students.English Language and Literature International Conference (ELLiC). (1). 46-55.

Yunus, M. Md. And Salehi, H. (2012) The Effectiveness of Facebook Groups on Teaching and Improving Writing: Students' Perceptions. International Journal of Education and Information Technologies, 1/6, 8/7-96.

Zappavigna, M. (2016). Social media photography: construing subjectivity in instagram images.

Zhang, Bin. (2008). On Grammatical Differences Between Daily British and American English. Asian Social Sience, 4 (6). 